\title{
SIKAP PRIA TERHADAP KESEHATAN REPRODUKSI DI SURABAYA
}

\author{
Ita Mardiani Zain \\ Jurusan Pendidikan Geografi, FISH, UNESA, Surabaya \\ Jl. Ketintang No 1, Ketintang, Surabaya
}

\begin{abstract}
Abstrak: Undang-undang perkawinan Indonesia menyatakan ada perbedaan usia untuk kawin antara pria dan perempuan. Batas minimal kawin untuk perempuan adalah 16 tahun, sedangkan pria minimal usia 19 tahun. Perbedaan ini tentu membawa dampak pada kesehatan seks dan kesehatan reproduksi. Mengacu kepada undang-undang perkawinan, sebagaimana disebutkan di atas, menunjukan bahwa perempuan, sebagai istri diposisikan di bawah pria. Tujuan penelitian adalah ingin mengetahui bagaimana sikap pria terhadap kesehatan reproduksi. Jenis penelitian ini adalah penelitian observasional dengan rancangan cross sectional. Populasi penelitian adalah pria dewasa yang telah menikah. Pengambilan sampel dilakukan secara multistage random sampling atau sampling acak bertahap. Terpilih kecamatan Tegalsari sebagai daerah urban ( Kelurahan Tegalsari, Dr. Sutomo, dan Wonorejo), kecamatan Tandes sebagai daerah sub urban (Kelurahan Manukan Kulon dan Tandes Lor) dan diambil secara random 200 pria dewasa dan telah menikah. Hasil penelitian adalah sebagian besar responden mempunyai sikap yang baik tentang kesehatan reproduksi, yaitu sebesar $60 \%$ di Kecamatan Tegalsari dan $61 \%$ di Kecamatan Tandes, jadi tidak ada perbedaan sikap tentang kesehatan reproduksi antara Kecamatan Tegalsari dan Tandes dengan tingkat kemaknaan $(\mathrm{p})=0,748$.

Kata kunci : sikap, pria, kesehatan reproduksi.
\end{abstract}

\section{A. PENDAHULUAN}

Keberhasilan Program Keluarga Berencana (KB) sebagai upaya untuk mengatur kelahiran dalam rangka peningkatan kesejahteraan ibu dan anak di Indonesia telah diakui masyarakat luas. Keberhasilan Program KB menurunkan angka kelahiran, perlu ditindaklanjuti dengan upaya membudayakan Norma Keluarga Kecil Bahagia Sejahtera (NKKBS). Hal Ini berarti, tekanan Program KB bukan hanya pada penggunaan alat kontrasepsi, tetapi juga pada pembudayaan kesehatan reproduksi.
Kesehatan reproduksi meliputi aman dari kemungkinan kehamilan yang tidak dikehendaki, terlindung dari praktek reproduksi berbahaya, bebas memilih kontrasepsi yang cocok baginya,mempunyai akses terhadap informasi kontrasepsi dan reproduksi mempunyai akses terhadap perawatan kehamilan dan pelayanan persalinan yang aman, serta mempunyai akses terhadap pengobatan (treatment) kehamilan. (Darwin, 1996).

Kesehatan reproduksi tidak bisa dilepas dari kontruksi gender (budaya), karena pengetahuan seseorang tentang reproduksi dan seks, dipengaruhi oleh 
budaya yang berkembang di masyarakat serta tingkat pendidikan seseorang. Di masyarakat tradisional yang tingkat pendidikannya rendah, kelaziman perilaku seksual yang beresiko tinggi, sikap diskriminasi dan pandangan negatif terhadap perempuan masih sering terjadi. Sikap dan pandangan yang demikian jelas akan berpengaruh terhadap kesehatan reproduksi.

Roudsari (2006) menyatakan bahwa pengetahuan, sikap dan praktik laki-laki, warga Iran dan pengungsi Afghanistan, mengenai kesehatan reproduksi mempunyai skor yang rendah, meskipun skor di kedua kelompok rendah, warga Afghanistan menunjukkan skor yang lebih rendah untuk sikap dan praktik. Akses ke layanan kesehatan reproduksi sama untuk kedua kelompok. Pengawasan lebih lanjut terhadap peran pria dalam kesehatan reproduksi, terutama faktor sosial dan budaya, sangat direkomendasikan.

Menurut Narang (2013) laki-laki India tetap menjadi otoritas dalam semua aspek kesehatan reproduksi mulai dari pembuatan kebijakan hingga implementasinya di tingkat akar rumput. Studi yang dilakukan terhadap 232 suami untuk menentukan kesadaran dan partisipasi pria dalam perawatan kesehatan ibu dan untuk menilai sikap mereka terhadap pasangannya, $61 \%$ dari peserta telah menemani istri mereka ke klinik antenatal pada satu waktu atau yang lain. Namun meskipun datang ke rumah sakit $60,1 \%$ tidak mengetahui komponen perawatan antenatal seperti jumlah imunisasi tetanus atau persyaratan peningkatan diet selama kehamilan. $\quad 44 \%$ laki-laki tidak menyetujui istri mereka yang bekerja di luar rumah. $30 \%$ pria mengaku telah menyiksa pasangannya secara fisik pada beberapa kesempatan. $31 \%$ kehamilan tidak direncanakan. $75,7 \%$ pria berpendapat bahwa ukuran keluarga ideal terdiri dari dua anak. Hanya 36,2\% pria mengetahui bahwa sterilisasi pria lebih aman daripada sterilisasi wanita. Laki-laki di India telah terpinggirkan dalam pengeluaran perawatan kesehatan antenatal dan reproduksi dengan kebijakan yang menekankan pada layanan dan infrastruktur lebih dari melibatkan laki-laki sebagai mitra yang bertanggung jawab. Perubahan dalam pengetahuan, sikap dan perilaku pria dan wanita adalah kondisi yang diperlukan untuk mencapai tujuan pembangunan milenium.

Bietsch (2015) membahas sikap pria terhadap keluarga berencana di Afrika Sub-Sahara dan menemukan bahwa sikap positif terhadap keluarga berencana telah meningkat di seluruh Afrika Sub-Sahara dalam dua dekade terakhir. Ada hubungan sikap positif dengan berbagai karakteristik demografis (usia, status perkawinan, 
pendidikan, dan agama) dan hubungan dengan berbagai bentuk diskusi tentang keluarga berencana (radio, televisi, teman, dan mitra). Terdapat persetujuan yang lebih tinggi pada usia yang lebih tua dan tingkat pendidikan yang lebih tinggi, dan tingkat persetujuan yang lebih rendah di antara Muslim dibandingkan dengan orang Kristen. Interaksi antara karakteristik dan diskusi keluarga berencana menunjukkan bahwa mendengar atau berbicara tentang kontrasepsi memiliki asosiasi yang berbeda untuk kelompok yang berbeda.

Yemane (2017) menyatakan bahwa pengetahuan dan sikap memiliki hubungan positif yang signifikan dengan keterlibatan pria dalam kesehatan reproduksi. Pengetahuan dan sikap secara signifikan mempengaruhi keterlibatan pria dalam kesehatan reproduksi.

Hajizadeh (2015) Kesehatan seksual dan reproduksi pria adalah salah satu masalah kesehatan masyarakat yang paling penting. Namun, kurang perhatian diberikan pada masalah ini, dibandingkan dengan masalah kesehatan wanita. Mayoritas pria $(75,1 \%)$ memiliki pengetahuan yang buruk dan sikap sedang $(67,3 \%)$ terhadap kesehatan seksual dan reproduksi. Kesimpulan: Berdasarkan temuan, pria merasa perlu untuk pendidikan kesehatan seksual dan reproduksi; kebutuhan ini dipengaruhi oleh faktor sosial dan demografi, kecuali status perkawinan. Jika pembuat kebijakan kesehatan memperhatikan kebutuhan pendidikan ini, adalah mungkin untuk mengimplementasikan program yang cocok untuk meningkatkan kesehatan dan pengetahuan seksual pria.

Penelitian yang berkaitan dengan sikap kesehatan reproduksi pria terutama dewasa di Indonesia masih sedikit. Penelitian di Indonesia banyak sekali penelitian yang sasarannya adalah remaja, seperti penelitian Sirupa (2016) menyatakan tingkat pengetahuan, sikap, dan perilaku remaja tentang kesehatan reproduksi. seluruh siswa kelas XI di SMK Negeri 1 Manado dan SMK Kristen Getsemani Manado sebanyak 200 responden. Terdapat 182 responden (91\%) memiliki pengetahuan yang baik dan 192 responden (96\%) memiliki sikap yang baik tentang kesehatan reproduksi. Perilaku remaja tentang kesehatan reproduksi menunjukkan adanya kecenderungan pergeseran nilainilai. Sebagian besar remaja memiliki pengetahuan dan sikap yang baik tentang kesehatan reproduksi. Perilaku seksual remaja dari yang tergolong ringan (seperti cium pipi) sampai tergolong berisiko tinggi (seperti hubungan seksual) telah dilakukan oleh remaja dalam penelitian ini.

Penelitian di Indonesia terutama berkaitan dengan pria dewasa yang telah menikah sangat menarik. Sehubungan 
dengan Undang-undang perkawinan Pasal 31 ayat 3 dan pasal 34 (UndangUndang Republik Indonesia No 1 Tahun 1974) menyatakan bahwa suami adalah kepala keluarga, dan istri adalah kepala rumah tangga. Pada pasal 34 ayat 1 dinyatakan bahwa kewajiban suami adalah memberi nafkah keluarga, sedangkan kewajiban istri adalah memelihara dan menjaga anak. Dari pasal tersebut menunjukan bahwa peran pria dalam bidang produksi, dan peran perempuan dalam bidang reproduksi. Dalam undang-undang perkawinan ada perbedaan usia untuk kawin antara pria dan perempuan. Batas minimal kawin untuk perempuan adalah 16 tahun, sedangkan pria minimal usia 19 tahun. Perbedaan ini tentu membawa dampak pada kesehatan seks dan kesehatan reproduksi. Mengacu kepada undangundang perkawinan, sebagaimana disebutkan di atas, menunjukan bahwa perempuan, sebagai istri diposisikan di bawah pria. Berdasarkan latar belakang di atas, penulis ingin mengetahui bagaimana sikap pria terhadap kesehatan reproduksi.

\section{B. METODE}

Pada penelitian ini, hanya dilakukan pengamatan saja tanpa ada perlakuan tertentu yang dikenakan pada obyek penelitian, maka jenis penelitian ini adalah penelitian observasional dengan rancangan cross sectional. Populasi penelitian adalah pria dewasa yang telah menikah. Pengambilan sampel dilakukan secara multistage random sampling atau sampling acak bertahap, dengan ketentuan sebagai berikut : Kota Surabaya dibagi menjadi dua kelompok besar yaitu urban (kota) dan sub urban (pinggir kota), jadi terdapat dua strata. Dari masing-masing strata dipilih secara random satu kecamatan, yang akan dijadikan lokasi penelitian.Dari masing-masing kecamatan terpilih (kecamatan Tegalsari sebagai daerah urban, kecamatan Tandes sebagai daerah sub urban), diambil secara random beberapa kelurahan. Dari kelurahan terpilih (Kecamatan Tegalsari : Kelurahan Tegalsari, Dr. Sutomo, dan Wonorejo; Kecamatan Tandes : Kelurahan Manukan Kulon dan Tandes Lor) diambil secara random 200 pria dewasa dan telah menikah.

Adapun sikap pria terhadap kesehatan reproduksi meliputi sikap tentang KB, jumlah anak yang diinginkan, pembatasan jumlah anak, anak laki atau perempuan sama saja, perlunya pemeriksaan kehamilan minimal sekali selama kehamilan, Dalam menentukan jumlah anak maka istri perlu diajak musyawarah, menentukan jumlah anak merupakan hak suami / pria, meskipun anak sudah lebih dari dua, tetapi belum mempunyai anak laki-laki, istri harus melahirkan lagi, Ketika istri sedang hamil, suami perlu membantu pekerjaan rumah 
tangga, Ketika istri sedang hamil, gizinya harus diperhatikan, Ketika istri sedang hamil, suami harus memberikan kasih saying, Jumlah anak tidak perlu dibatasi, sebab setiap anak membawa rejeki sendiri-sendiri, Dalam melakukan hubungan seks tidak boleh memaksa istri, Istri perlu dilibatkan dalam merencanakan kehamilan, Istri sedang menyusui perlu mendapat makanan tambahan, melakukan hubungan seks dengan orang yang bukan istrinya (melacur/selingkuh) dapat menimbulkan penyakit kelamin

\section{HASIL DAN PEMBAHASAN}

Sampel penelitian adalah 200 pria yang telah menikah, yang terdiri dari 100 pria dari Kecamatan Tegalsari dan 100 pria dari Kecamatan Tandes, diperoleh data bahwa responden pria di Kecamatan Tegalsari rata-rata berusia 34,99 tahun dengan usia paling muda 20 tahun dan yang paling tua 60 tahun. Responden pria dari Kecamatan Tandes rata-rata berusia 37,22 tahun dengan usia yang paling muda 23 tahun dan yang paling tua 64 tahun.

Pendidikan responden baik di di wilayah Kecamatan Tegalsari dan Kecamatan Tandes sebagian besar adalah SLTA ke atas sekitar 76-78\%, hanya sebagian kecil lulusan SD $(<6 \%)$. Pekerjaan responden sebagian besar adalah swasta sekitar 53-65 \%, pegawai negeri dan abri berkisar 10-18 \%, lainnya ada yang bekerja sebagai pedagang, buruh, pensiunan, sopir, penjahin da nada yang tidak bekerja.

Sikap responden tentang $\mathrm{KB}$ sebagian besar responden setuju tentang adanya KB yaitu $95 \%$, sisanya tidak setuju, sama di kedua kecamatan. Alasannya beragam antara lain membentuk keluarga sejahtera, untuk kualitas anak seperti pendidikannya di kemudian hari, serta untuk menjaga kesehatan. Sikap kesehatan reproduksi yaitu tentang persetujuan jumlah anak yang diinginkan, di kedua kecamatan rata-rata mempunyai sikap yang baik sekitar 54-62 \%. Responden sebagian besar menginginkan jumlah anak dua sekitar 53-55\%, sekitar 30-40\% masih ada responden yang menginginkan jumlah anak tiga dan empat.

Sikap responden tentang jumlah anak apakah perlu dibatasi, sebagian besar responden setuju yaitu sekitar 91$92 \%$. 87-96 \% responden menyatakan setuju bahwa anak perempuan dan lakilaki sama saja. Sebanyak 94-99 \% responden setuju bahwa penentuan jumlah anak perlu dimusyawarahkan dengan istri. Responden tidak setuju terhadap sikap tentang penentuan jumlah anak adalah hak suami sebesar 76-79 \%. Responden yang tidak setuju jika anak lebih dari dua dan belum mempunyai anak laki-laki, istri harus hamil lagi, ada sebesar $76-78 \%$. Ada sekitar 71-79\% responden yang tidak setuju bahwa jumlah anak tidak perlu dibatasi, karena 
masing-masing anak membawa rejeki masing-masing. Berdasarkan uraian di atas ternyata masih ada sekitar 21-24\% sikap yang setuju terhadap sikap tentang penentuan jumlah anak adalah hak suami, demikian pula dengan kesukaan terhadap anak laki-laki, masih sekitar 22-24\% responden yang menginginkan istrinya hamil kembali, serta masih ada yang setuju jumlah anak tidak perlu dibatasi sekitar 21-29\%.

Responden di kedua kecamatan ada sekitar $77-79 \%$ yang setuju bahwa minimal sekali memeriksakan istri ke tenaga kesehatan selama kehamilan, dan sisanya masih ada responden yang tidak setuju. Sikap suami yang setuju membantu pekerjaan rumah tangga ada sekitar 87-99 \%, ini sangat menggembirakan peneliti. Demikian pula dengan sikap responden dalam memperhatikan gizi selama istri hamil, memberikan lebih kasih sayang selama kehamilan, istri menyusui perlu diberi makanan tambahan, ternyata di kedua kecamatan semua responden $100 \%$ setuju.

Responden baik di kecamatan Tegalsari maupun Tandes mempunyai sikap yang baik, mereka setuju dalam berhubungan seksual, mereka tidak boleh memaksa istri mereka, yaitu sekitar 78-89\%, artinya masih ada sikap yang kurang baik, masih ada yang yang tidak setuju. Perencanaan kehamilan perlu melibatkan istri, sikap tersebut disetujui oleh sekitar 95-97\% reponden. Responden setuju bahwa melacur dapat menimbulkan penyakit kelamin sekitar $86-90 \%$, sehingga sangat disayangkan tidak semua setuju dengan sikap tersebut.

Berdasarkan indikator-indikator sikap terhadap kesehatan reproduksi, dan dilakukan kategori jika responden dapat menjawab pertanyaan lebih dari $60 \%$, maka dikategorikan berpengetahuan baik. Jika mampu menjawab pertanyaan kurang dari $60 \%$, maka dikategorikan berpengetahuan kurang. Hasilnya adalah sebagian besar responden mempunyai sikap yang baik tentang kesehatan reproduksi, yaitu sebesar $60 \%$ di Kecamatan Tegalsari dan $61 \%$ di Kecamatan Tandes.

Berdasarkan uji Chi-Square, yang berusaha melihat ada atau tidaknya perbedaan pengetahuan responden tentang kesehatan reproduksi berdasarkan daerah responden, didapatkan bahwa responden dari daerah urban yaitu Kecamatan Tegalsari ratarata mempunyai sikap tentang kesehatan reproduksi yang sama dengan responden dari daerah sub urban yaitu Kecamatan Tandes dengan tingkat kemaknaan $(\mathrm{p})=$ 0,748 .

Khajehei (2013) menyatakan kesehatan seksual mempengaruhi kesejahteraan umum dan kualitas hidup secara keseluruhan semua pria dan wanita. Di Iran diperlukan pendidikan 
khususnya konseling pranikah untuk meningkatkan pengetahuan dan sikap orang dewasa baik pria dan wanita terhadap kesehatan reproduksi.

Menurut A. Vanusha (2018) pendidikan dan sikap pria, pengetahuan dan kesadaran, faktor sosial budaya, faktor psikologis, faktor sistem kesehatan, dan kebijakan memainkan peran penting dalam keterlibatan pria dalam kesehatan reproduksi. Programprogram tentang implementasi yang efektif dari keterlibatan laki-laki dalam prakarsa kesehatan reproduksi harus mengatasi hambatan dan tantangan terhadap kegiatan pendukung laki-laki. Studi ini juga menyarankan peningkatan literasi kesehatan reproduksi di kalangan pria yang meningkatkan kepositifan mereka dan memotivasi mereka untuk berpartisipasi dalam layanan kesehatan reproduksi.

\section{KESIMPULAN}

Sikap responden terhadap kesehatan reproduksi cukup baik, tidak ditemukan karakteristik tertentu yang membedakan sikap responden terhadap kesehatan reproduksi. Sikap yang baik ini kemungkinan disebabkan oleh pendidikan responden yang sebagian besar SLTA ke atas, pengetahuan yang cukup baik serta faktor sosial budaya yang dimiliki oleh responden.

\section{E. SARAN}

Peningkatan sikap pria dalam kesehatan reproduksi yaitu dengan meningkatkan paparan Komunikasi Informasi Dan Edukasi (KIE) mengenai kesehatan reproduksi dengan melalui media yang efektif seperti TV, radio, poster, dan lain sebagainya. Atau dengan meningkatkan peran keteladan tokoh masyarakat dan tokoh agama akan pentingnya sikap pria dalam kesehatan reproduksi. Dapat pula dengan memperbaiki isi informasi pada buku, majalah, film, sinetron, dan lain-lain yang mengemukakan tentang sub ordinasi perempuan.

\section{DAFTAR PUSTAKA}

A. Vanusha, Parvathavarthini K. 2018. Assessment of present awareness on reproductive health and evaluation of a tool designed for reproductive health education among school going adolescent girls. International Journal of Reproduction, Contraception, Obstetrics and Gynecology. Jun;7(6):2381-2387

Bietsch,Kristin E Bietsch, 2015. Men's Attitudes Towards Contraception in Sub-Saharan Africa.

African Journal of Reproductive Health September 2015; 19 (3): 41

Darwin Muhadjir. 1996. Gerakan Kependudukan : Dari Keluarga Berencana ke Kesehatan Reproduksi, dalam Penduduk Dan Pembangunan, Editor Agus Dwiyanto dkk, Pusat Penelitian Kependudukan Universitas Gadjah Mada, Yogyakarta.

Hajizadeh Marjan (MS)1, Mojgan Javadnoori, Nahid Javadifar. 2015. 
Educational Needs of Adult Men regarding Sexual and Reproductive Health in Ahvaz, Iran. Journal of Midwifery \& Reproductive Health Vol 3 No. 3 385-393

Khajehei Khajehei M.,S. Ziyadlou and A. Ghanizadeh, 2013, Knowledge of and attitudes towards sexual and reproductive health in adults in Shiraz: a need for further education. Eastern Mediterranean Health Journal, EMHJ . Vol. 19 No. 12 • 2013

Narang, Harkiran, Seema Singhal, (2013) Men as partners in maternal health: an analysis of male awareness and attitude. International Journal of Reproduction, Contraception, Obstetrics and Gynecology . Sep;2(3):388-392

Roudsari H.R. Sadeghipour1 R. Sherafat-Kazemzadeh, M. Rezaeie1 and M. Derakhshan, 2006. Reproductive health knowledge, attitudes and practices of Iranian and Afghan men in Tehran province. La Revue de Santé de la Méditerranée orientale, Vol. 12, No 6, 2006

Sirupa, Tirsa A. Sirupa, John J.E. Wantania, Eddy Suparman, 2016, Pengetahuan, sikap, dan perilaku remaja tentang kesehatan reproduksi. Jurnal E Clinic. Vol 4, No. 2.

Yemane Yayehyirad, 2017. Assessment of Knowledge, Attitude and Practice Towards Reproductive Health Service among Mizan Tepi Universtiy Tepi Campus Students, Sheka Zone, South Nations Nationalities and Peoples Regional State,South West Ethiopia, 2017. Jurnal of Hospital and Medical Management. Vol. 3 No. 1: 11 